\title{
Stakeholder's Perception of Industrialized Building System (IBS) Implementation
}

\author{
Izatul Laili Jabar, Faridah Ismail, Abdul Rashid Abdul Aziz \\ Faculty of Architecture, Planning \& Surveying, \\ Universiti Teknologi MARA, Shah Alam, Selangor, Malaysia. \\ izatul_laili@salam.uitm.edu.my; farid346@salam.uitm.edu.my; abdulrashid.abdulaziz@gmail.com
}

\begin{abstract}
The Malaysian Government has put a great effort in promoting the usage of industrialized building system (IBS) in the construction industry. However, the implementation is still far from the expected outcome. Even many advantages have been offered by IBS implementation; the stakeholders still hold many negative perceptions towards its applicability. These perceptions are one of the contributing factors to the poor adoption of IBS components in the construction industry. This research studies the perception of major stakeholders in the IBS construction project and suggestions have been put forward to overcome the situation.
\end{abstract}

Keywords: Perspective, Stakeholders, IBS Adoption, IBS issues

eISSN 2398-4295 @ 2018. The Authors. Published for AMER ABRA cE-Bs by e-International Publishing House, Ltd., UK. This is an open-access article under the CC BY-NC-ND license (http://creativecommons.org/licenses/bync-nd/4.0). Peer-review under responsibility of AMER (Association of Malaysian Environment-Behaviour Researchers), ABRA (Association of Behavioural Researchers on Asians) and cE-Bs (Centre for EnvironmentBehaviour Studies), Faculty of Architecture, Planning \& Surveying, Universiti Teknologi MARA, Malaysia.

DOI: http://dx.doi.org/10.21834/ajbes.v3i10.90 


\subsection{Introduction}

The Malaysian government and practitioner have introduced the Industrialized Building System (IBS) to Malaysian construction industry which covers pre-assembly, prefabrication, Modern Method of Construction (MMC), Off-site Manufacturing (OSM), Off-site Production (OSP) and Off-site Construction (OSC). As stipulated in "Garis panduan dan peraturan perancangan bangunan" by UPE, (2008) starting from the year 2008 and above, public buildings project must contain at least $70 \%$ of IBS score. However, despites all the promotions, encouragements, and incentives from the government, till now the level of IBS adoption is far from the targeted plan. This paper aims to investigate the perceptions and subsequently the suggestions on improving the poor reception of Industrialized Building Systems by major stakeholder involved in IBS construction project.

\subsection{Literature Review}

\section{Industrialized building system (IBS): the issues and challenges.}

Lessing et.al., (2005) describes IBS as an integrated manufacturing and construction process with a well-planned organization for efficient management, preparation, and control over resources used, activities and results supported by the used of highly developed components. The process of IBS construction started with the manufacturing of component off-site or mass production on the site, once completed, the components will be delivered to the construction site for assembly and erection (Hamzah et al., 2010). The purpose of IBS implementation is to improve performance and quality in construction and also to reduce the dependency on foreign construction labor (Hamid et al., 2007). The use of IBS will overcome the issues of repetitive part of the building but difficult, time-consuming and costly labor at the site. Simultaneously, parts of benefits on IBS adoption includes the reduction of unskilled workers, less wastage, less volume of building materials, speedier construction time, increased environmental and construction site cleanliness, reduced risk by improving health and safety, proper coordination and management. (Kamar et al., 2010). Even though, the uptake of IBS component acknowledged by the construction industry players but the percentage of its application is still below the national target (Hamid et al., 2008). It was due to several issues that create a barrier to IBS usage among the stakeholder. This barrier prevents the full adoption of IBS in the construction industry. The problems of the IBS implementation can be grouped into technical issues and human issues (Pan et al., 2004). The issues as discussed by several scholars are summarized in Table 1.

Table 1: Technical and human issues

ISSUES 
Site specifics and delivery issues, interfacing problems, economies of scale (Pan et al., 2004) Lack of knowledge among designers (Kamar et. al., 2007)

Poor quality products, Lack of technical knowhow, low off-site manufacturing of construction components, mechanization and standardization (Kamar et. al., 2007) Insufficient incentives, sheer cost investment, low component standardization (Hashim et. al., 2011)

The availability of cheap foreign labor(Hashim \& Kamar, 2011)

Inflexibility of IBS components, the weakness of connection and jointing system (Qays et al. 2010)

The process employed to construct a facility influence the project duration (Hashim et al., 2011)

Poor quality control and lack of technical experience (Idrus et al., 2008)
Inadequate corroborative scientific research is undertaken, poor response from the industry players (Thanoon, 2003)

The need for mindset change (Kamar et. al. 2007)

Bad perception of IBS (Qays et al., 2010)

The fragmentation and diversity in the construction industry sector (Qays et al., 2010)

Workforce/human capacity to appreciate the change (Nadim\& Goulding 2010)

Lack knowledge \& exposure to IBS technology (Rahman \& Omar, 2006)

Lack of knowledge on the use and benefits of IBS (Pan et. al., 2007)

Extensive coordination required before construction operations (Haas \& Fagerlund, 2002)

Lack of integration among relevant player (CIDB 2007)

Require on-site specialized skills (Kamar et al., 2011)

Lack skilled worker (Nadim\& Goulding 2010)

Insufficient training on site levels (Pan et. al., 2007)

Potential for loss of management (Rahman \& Omar, 2006)

Based on the issues tabulated in Table 1, it is believed that parts of it formed a negative perception to the stakeholders of the IBS construction project. This perception will indirectly prevent them from being an IBS user. Even, since the introduction of IBS and its promises to improve the current construction method and scenario in Malaysia, the perception towards its applicability has become one of the issues.

\section{Perceptions towards IBS}

Changing people's mindset regarding their perception towards IBS adoption is one of the critical success factors to enhance the IBS implementation in Malaysia (CIDB, 2010). As addressed by Zawawi (2009), despite its many benefits promoted, the different perceptions among the stakeholders has led to the low usage of IBS components in the construction industry. Rahman \& Omar (2006) stated that the reasons that contribute to the negative conception of IBS term are past failures and unattractive architecture. These buildings are commonly associate with lower quality buildings, leakages, abandoned projects, unpleasant architectural appearances and other drawbacks. Due to the poor architectural design, the old pre-fabricated buildings have given the public, the wrong impression about precast concrete. Customer rejection is the main fear of clients in implementing the IBS. On the other hand; even the construction professionals are uncertain with IBS technology and relate IBS with potential post-construction problems.

Scholars agreed that the poor perception towards IBS is based on the historical failure of off-site practices to deliver improved performance, technical difficulties (e.g. Site specifics, delivery issues, interfacing problems and cost), lack of opportunities for benefiting from economies of scale, structural requirements associated with social, security, privacy and 
noise problems and the fragmented structure of the construction supply chain (Blismas\& Wakefield, 2009; Idrus et al., 2008; Pan at al., 2004). Additionally, most of the industry stakeholders are reluctant to change to the new construction method as they have to embrace new ways of thinking and working (Nadim\& Goulding, 2010). On the other hand, the client prefers the risk adverse attitude to avoid any upcoming difficulties related to IBS application. At the same time, most of the contractors are already convenient and familiar with the traditional method since the technology suits them well; changing to industrialized construction means that the additional cost of labor training and new machinery required (Kamar, 2011). Therefore, investment in human capital development is vital to gain the experience, enhance the technical knowledge and training of skilled labor (Hamid et al. 2008; CIDB, 2008; Rahman and Omar, 2006 and Thanoon et al. 2003). Aburas, (2011) and Onyeizu at al., (2011) stated that the good perception plays an important role to achieve desired IBS adoption. Amongst the example of poor perception in IBS are: IBS is not popular among architects and designers due to misconception that IBS will eventually limit their creativity in building design and as for building users, IBS buildings are fragile and impermanent structure, IBS building is also seen as non-renovated structure (Sadafi et al., 2011). Thus, it makes IBS based building as a non-popular choice in attracting the buyer or tenant in the future. Therefore, changing the people mindset and perception about IBS usage is also an important issue to consider. Literature has identified and grouped the perceptions into four major stakeholders who are client/developer, contractor, designer (architect and engineer) and the buyer. The details for each group are depicted in Table 2.

Table 2. Stakeholder's perceptions towards IBS

\begin{tabular}{ll}
\hline STAKEHOLDER & PERCEPTIONS \\
\hline Contractor & Unfamiliar method of working (Idrus. A, et al., 2008) \\
& High initial cost, financial failure (Idrus et al., 2008) (Hassim,2009) \\
& Difficulties in applying changes in the middle of site work (Sadafi et al., 2011) \\
& Potential for loss of management control \\
& Require a huge volume of works to break-even on the investment (Pan et al., 2007) \\
& Logistic cost is perceived to be expensive (Nadim\& Goulding, 2011) \\
& The process employed to construct a facility influence the project duration \\
& Difficulties in the production facility logistics and stock management \\
& Skill worker requirement (Nadim\& Goulding, 2011) \\
& Lack of knowledge of the construction process of IBS, lack of experience and \\
& requirement of new technical knowledge (Hamid et al., 2008) \\
& Required high coordination (Kamar et al., 2012) \\
& \\
& \\
& IBS will spoil the authentic 'traditional' house image (Edge et al., 2002) \\
Low quality of building materials and poor workmanship (Pan et al., 2004) \\
IBS can only produce monotonous design (Hussein, 2007) \\
Unattractive modular buildings, bad architecture (Kamar et al.,2009) \\
Issues of renovation (Sadafi et al., 2011) \\
Leakage and crack problem (Sadafi et al., 2011)
\end{tabular}




\begin{tabular}{ll}
\hline Client & Perceive perception in terms lack flexibility, low-quality finishes, leaky \\
& accommodation, unfamiliar materials, etc. (Nawi et al., 2011) \\
& IBS restrictive and unable to deliver customer desires (Boyd, et al., 2012) \\
& IBS is rigid and not flexible enough. (Hussein, 2007) \\
& Poor quality product available in Malaysia (Kamar et. al., 2009) \\
& Technology transfer in IBS is a failure, and conventional in-situ system is more \\
& attractive (Idrus, 2008) \\
& Maintenance problem (Sadafi et. al., 2011) \\
& IBS is a fragile and impermanent structure (Aburas, 2011) \\
& High-risk process and not contributing to any benefit to the building owner (Kamar et \\
& al., 2009) \\
& Design philosophy issue (Madigan, 2012) \\
& Issue of adaptability, customizability, flexibility, quality of interfaces for buildings \\
& (Nadim\& Goulding, 2011) \\
Designer & Not flexible enough to meet architectural design (Sadafi et. al., 2011) \\
& Applicability in design (Onyeizu et al., 2011) \\
& Potential of post-construction problems (Rahman \& Omar, 2006) \\
\hline
\end{tabular}

\subsection{Methodology}

Accordingly, in addressing the issue on poor perceptions in IBS implementation, an investigation of major stakeholder's perception towards IBS that hinders successful IBS implementation has been carried out. The perception is based on the Malaysian context and supported by the worldwide literature. The examination is through a critical review of the available relevant literature on the system from various books and article. This study reviewed 50 existing kinds of literature on IBS in Malaysia and worldwide. To develop new findings, the limit of this research is from the year 2000 to 2014.

\subsection{Results and Discussions}

The discussions on how to create a better perception of the major categories of stakeholder as follows:

\section{Client}

A client with good knowledge and awareness of IBS benefit will undoubtedly encourage designers to design a building according to IBS (Kamar at al., 2009). According to the IBS Roadmap Review (2007), the adoption of IBS in Malaysia is a client driven. Thus, the client plays a major role in decision making whether to use IBS or not. In line with that, the comprehensive awareness program and showcases of best practices for the client and decision makers should be held, for them to get the correct information on IBS (Aburas, 2011; Kamar et al.,2009; Rahman \& Omar, 2006). The advantage and disadvantages of adopting IBS should be more objective in briefing the client (Pan et al., 2004). On the other hand, associated agency such as CIDB should test and demonstrate that IBS can deliver as good or better performance than traditional methods (Pan et al., 2007). 


\section{Contractor}

Even the adoption of IBS in Malaysian construction industry started as early as 1960's, but it still needs support from the government to improve the construction sector to move from the conventional system and use IBS (Qays et al., 2009). The contractors should be provided with guidance on the project decision-making process and the site integration of IBS (Pan et al., 2007). On the other hand, the government should initiate a forum on a regular basis of academics and associated practitioners active in IBS for the exchange of information and experience, development of new techniques and advice on promotion and implementation of IBS to the contractors (Hamid et al., 2011). According to Haas \&Fagerlund (2000) the contractor should be made understand that the skill level required for prefabrication and preassembly workers is no different from traditional stick-build construction. Apart from that limiting the number of foreign workers who work at the construction site also can be one of the efforts to encourage the contractors in learning and adopting IBS. In overcoming the issues of low-quality product, delay and cost overrun, implementing contractor's earlier involvement in the project life cycle is the best solution. Besides, it ensuring the contractor got involved and able to express their opinion as early as in the design stage to enhance their understanding of the construction using IBS (Nawi et al., 2009).

\section{Buyer}

The buyer often skeptical with IBS building due to the quality issue (leakage and crack problem), unattractive past design and inflexibility of renovation. Thus, to improve the perception of low quality, it is recommended to improve training in installation techniques by addressing interfacing and tolerance issues and avoiding any faulty during the installation process (Pan et al., 2004). At the same time, manufacturers must ensure that the components of IBS design should pass the quality control measures/department before sending to the site. The installer should be an expert or experienced (Nawi et al., 2007). Regarding inflexibility of renovation, the buyer should be explained about the availability of a hybrid system that caters for them who often renovates but at the same time keeping the structure intact. This system offers less wastage and provides speed to the contractor at no costs and extra headroom, a consistent finish and flexibility for renovation (Nawi et al., 2007).

\section{Designer}

Designer perception about IBS is of the applicability in the design which they think IBS is not flexible for architectural design (Onyeizu et al., 2011). Therefore, the designers should be informed about the varieties of product ranges and options that they can adopt in their design rather than rely on the solutions offered to them. Once the designer had clear options on what they can choose and how much it costs, it hence their better visibility in the design of IBS building (Nadim\& Goulding, 2011).Other than focusing on these key players, other general recommendations to enhance the stakeholder perception on IBS also should be taken into consideration. Amongst others are educating all the stakeholders in IBS from the policy makers and decision maker to consumers about the use of IBS and its benefits as an essential starting point (Aburas, 2011). Apart from that, Abdullah \&Egbu, (2010) suggested that the negative connotations and the perception of IBS need to be conquered, for more 
information to decision makers to make a consideration of IBS implementation. As stated by Jabar et al., (2013), identification of the issues will provide a better understanding and a clearer picture of problems that hinder the full adoption of IBS in Malaysia. At the same time, Rahman \& Omar (2006) advised that IBS should be branded as a value for money solution with quality, whole life cycle costing, and environmentally friendly to change the customer's perception of past failure and bad architecture. In short, there is an urgent need to change people mindset regarding IBS through promotion, awareness programs and education.

\subsection{Conclusion}

Changing people mindset is one of the critical success factors in IBS implementation. To shift the mind paradigm, the issues in IBS that leads to the poor perceptions are investigated. The stakeholders are identified and categorized into four major groups consists of contractor, buyer, client and designer. Their perceptions towards IBS are examined. Based on Table 1 literature research shows that, among the stakeholders, contractor holds many negative perceptions towards IBS usage. It is due to the facts that the contractor is the main actor in a construction project, and there are many things that they have to consider before changing their method of working and thinking. Besides that, a real usage of IBS only can be seen during the construction phase, which handled by the contractor; thus, it required them to give more judgment on IBS. Identification and categorizing the perception of the stakeholders will help the respective parties, such as CIDB to take necessary actions in overcoming the situation. Simultaneously, enhancing and giving better perception towards IBS will create a better understanding and demand for IBS adoption.

\section{References}

Aburas, H. (2011). Off-site Construction in Saudi Arabia: The Way Forward. Journal of Architectural Engineering, $17(4), 122$.

Alinaitwe, H. M., Mwakali, J., \& Hansson, B. (2011). Assessing The Degree Of Industrialisation In Construction A Case Of Uganda. Journal of Civil Engineering and Management, (September 2011), 37-41.

Anuar, K., Kamar, M., Alshawi, M., Hamid, Z. A., \& Nasrun, M. (2009). Industrialized Building System (IBS): Identifying Critical Success Factors (CSFs). In Proceedings of 2 Construction Industry Research Achievement International Conference (CIRAIC), 3rd - 4th November 2009, Kuala Lumpur, (pp. 1-11).

Blismas, N., \& Wakefield, R. (2009). Drivers, constraints and the future of off-site manufacture in Australia. Construction Innovation, 9 (1), 72-83.

Boyd, N., Khalfan, M. M. a., \& Maqsood, T. (2012). Off-Site Construction of Apartment Buildings: A Case Study. Journal of Architectural Engineering, 46.

CIDB. (2010). The Critical Success Factors (CSFs) for the Implementation of Industrialized Building System (IBS) in Malaysia. (Kamarul Anuar Mohamad Kamar, Z. A. Hamid, S. F. A. Sani, M. K. Ghani, M. Z. M. Zin, A. H. Rahim, \& A. Z. A. Karim, Eds.)3rd IBS Roundtable Workshop (IRW03) - CIDB/CREAM IBS Survey 2010. 
Ismail, F., Yusuwan, N. M., \& Baharuddin, H. E. (2012). Management Factors for Successful IBS Projects Implementation. ASIA Pacific International Conference on Environment-Behaviour Studies, Giza, Egypt (Vol. 00).

Gibb, A. G. F. (2001). Standardization And Pre-Assembly- Distinguishing Myth From Reality Using Case Study Research. Construction Management and Economics, 19(3), 307-315.

Hamid, Z. A., \& Kamar, K. A. M. (2012). Aspects of off-site manufacturing application towards sustainable construction in Malaysia. Construction Innovation: Information, Process, Management, 12(1), 4-10.

Hashim, M. S., \& Kamar, K. A. M. (2011). Experiences and Lesson Learned on IBS Construction in Malaysia. In Z. A. Hamid, M. N. A. Azman, K. A. M. Kamar, Z. Ismail, A. S. A. Shukor, M. F. Mohammad,F. Ismail (Eds.), Industrialised Building System (IBS) : Definition, Concept, and Issues.

Hussein, T. S. J. (2007). Industrialized Building System: The Challenges and Way Forward. In Construction Industry Research Achievements International Conference (pp. 1-12).

Idrus, A., Hui, N. F. K., \& Utomo, C. (2008). Perception of Industrialized Building System ( IBS ) Within the Malaysian Market. International Conference on Construction and Building Technology, ICCBT2008, (07), 75-92.

Jabar, I. L., Ismail, F., Aziz, N. M., \& Janipha, N. A. I. (2013). Construction Manager's Competency in Managing the Construction Process of IBS Projects. In Procedia - Social and Behavioral Sciences (Vol. 105, pp. 85-93). Elsevier B.V.

Jabar, I. L., Ismail, F., \& Mustafa, A. A. (2013). Issues in Managing Construction Phase of IBS Projects. In Procedia - Social and Behavioral Sciences (Vol. 101, pp. 81-89). Elsevier B.V.

Kamar, Kamarul Anuar Mohd. (2011). An Investigation Into The Critical Success Factors of Industrialized Building System (IBS) Contractors: The Malaysian Case. University of Salford, United Kingdom.

Majid, Taksiah A, Nor, M., \& Azman, A. (2011). Quantitative Analysis On The Level Of IBS Acceptance In The Malaysian Construction Industry. Science And Technology, 6(2), 179-190.

Nadim, W., \& Goulding, J. S. (2011). Offsite Production: A Model For Building Down Barriers: A European Construction Industry Perspective. Engineering, Construction and Architectural Management, 18(1), 82-101.

Onyeizu, E. N., Hassan, A., \& Bakar, A. (2011). The Utilization of Industrialised Building System in Design Innovation in Construction Industry. Applied Sciences, 15 (2), 205-213.

Pan, W., Dainty, A. R. J., \& Gibb, A. G. F. (2012). Establishing and Weighting Decision Criteria for Building System Selection in Housing Construction. Journal of Construction Engineering and Management, 138 (11), 1239-1250.

Qays, M., Mustapha, K. N., Al-mattarneh, H., \& Mohamed, B. S. (2010). The Constraints of Industrialized Building System from Stakeholders 'Point of View. In ICSE2010. 